\title{
Flipping the Classroom for Optimizing Undergraduate Students' Motivation and Understanding of Medical Physics Concepts
}

\author{
Ali Khaled Bawaneh ${ }^{1 *}$, Ahmed Boudjema Hamida Moumene ${ }^{2}$ \\ ${ }^{1}$ Deanship of Academic Development at Imam Abdulrahman Bin Faisal University, SAUDI ARABIA \\ 2 Professor at Deanship of Preparatory Year and Supporting Studies Imam Abdulrahman Bin Faisal University, SAUDI ARABIA
}

Received 6 Jun 2020 • Accepted 24 September 2020

\begin{abstract}
The purpose of this study was to investigate the effects of the flipped classroom on optimizing students' motivation and understanding of medical physics concepts. This approach transfers teacher-fronted lessons out of class to be prepared by students at home and utilizes their class time for discussion and practice. The sample included 123 female students: 58 in a flipped classroom and 65 in a conventional classroom. Three instruments were developed: teachers' guide, an understanding test, and students' motivation questionnaire. Data were analyzed using the mean, standard deviation, ANCOVA - test, and size effect. The results showed that there were statistically significant differences among students' increased motivation and understanding of medical physics concepts in favor of the flipped classroom learning. Therefore, instructors and curriculum developers should restructure the contents of their courses according to flipped classroom principles to foster students' motivation and understanding of medical physics concepts.
\end{abstract}

Keywords: flipped classroom, medical physics concepts, optimizing motivation, learning physics

\section{INTRODUCTION}

Understanding the concepts of medical physics represents a challenging task that the students at Imam Abdulrahman Bin Faisal University, Dammam, Saudi Arabia, have to cope with within the course of their studies. Students following conventional teaching methods expect their teachers to provide them with all the bits and pieces of the course contents. They rely on spoon-feeding and rote memorization to regurgitate the absorbed contents on the day of the exam (Bawaneh, Moumene, \& Aldalalah, 2020; Bawaneh, Zain, \& Salmiza, 2010a; Moumene, 2010). This form of passive learning where students are considered as empty recipients to be filled up by teachers will inevitably not last long but will spawn parroting generations only fit for delivering their noble message through mimicry in their career.

Educators, on their part, seem to disdain this transmission approach and strive to motivate students and heighten their understanding through a novel approach. To address this issue, they question the traditional methodology followed in dispensing the contents of the courses to the students. As a consequence, an arsenal of research studies come to the scene suggesting the use of the flipped classroom as an alternative to the conventional teaching approach. This approach swaps teachers and students' roles in a sense that students prepare at home the lessons traditionally done in class by the teacher and utilize class time for discussion and practice under his guidance.

Despite the existence of abundant empirical literature on the expediency of this blended learning pedagogy, instructors seem to be apprehensive because of the novelty of this approach and its groundbreaking undertakings with the well-acquainted traditional beliefs in education. Nevertheless, the implementation of Information Communication Technologies throughout the world heralded promising revolutionary changes in the field of education at large. This sweeping reform is not a vagary of fashion but a real contribution to the improvement of the teaching profession and the development of 21st-century skills. 


\section{Contribution to the literature}

- The paper stresses the importance of using the flipped classroom model in promoting students motivation and understanding of medical physics.

- This model offers adequate solutions to students' autonomy, engagement and active learning laying more emphasis on innovative learner-centered orientations.

- The flipped classroom model supports the use of various types of information communication technology such as Blackboard, You Tube, audio and video records, social media, and other Online applications.

To address the above-mentioned problems, we tried to implement the flipped classroom as an innovative blended active learning approach to help students deepen their understating of physics medical concepts and boost up their motivation. This approach seems to develop students' autonomy, inquisition, responsibility for learning, adequate research skills, critical thinking and problem-solving activities (Bawaneh, et al. 2012; Broman \& Johnels, 2019; Lundin et al. 2018; Seery, 2015; Tütüncü \& Aksu, 2018). In this model, teachers provide students with handouts and video-recorded lectures selected from the program as learning resources, and students are required to study them before their scheduled lectures to be ready for active classroom discussion.

\section{Research Questions}

1. Is the use of the flipped classroom method more effective than the conventional teaching method in heightening students' understanding of medical physics concepts?

2. Is the use of the flipped classroom method more effective than the conventional teaching method in enhancing students' motivation towards learning physics?

\section{FLIPPED CLASSROOM LEARNING}

Academic research has always strived at finding new effective teaching approaches. Nowadays, the challenge is to find out an appropriate model for involving students in the process of learning and making them responsible for their pedagogical achievement using technology. Researchers such as Bellanca and Brandt (2010) stress the necessity of a total reconsideration of students' learning strategies to meet $21^{\text {st }}$ century skills. Villalba, Castilla, and Redondo-Duarte (2018) also stress the need for a crucial debate on the future of education and the provision of innovative methods for motivating students to learn through effective ways. Today, one of the most researched methodologies in higher education is the flipped classroom (Broman \& Johnels, 2019; Lundin et al. 2018; Seery, 2015; Tütüncü \& Aksu, 2018).

There are various definitions apropos flipped classroom learning in recent literature, but most of them converge on the inversion that what was done in class should be done at home and what was done at home should be done in class. Abeysekera and Dawson (2015) define the flipped classroom as a set of pedagogical approaches that: (1) move most informationtransmission teaching out of class, (2) use class time for learning activities that are active and social and (3) require students to complete pre- and/or post-class activities to fully benefit from in-class work. Låg and Sæle (2019) put forward a neutral definition for the flipped classroom is a sense that teacher-centered instruction is moved out of the classroom to free up time for more student-centered learning activities. Instead of using the traditional approach which is based on the transmission of knowledge, teachers just provide students with the materials and let them prepare the lessons for themselves. Demirel (2016) asserts that flipped learning gets the traditional classes all upside down. The teacher and students just swap roles inside and outside the class so as students take control of their learning. In an attempt to provide a clear-cut demarcation of flipped learning, the Flipped Learning Network (2014) dispensed the following definition:

Flipped Learning is a pedagogical approach in which direct instruction moves from the group learning space to the individual learning space, and the resulting group space is transformed into a dynamic, interactive learning environment where the educator guides students as they apply concepts and engage creatively in the subject matter.

Although researchers provide different definitions for the concept of the flipped classroom, all of them admit that it is a matter of swapping roles between the teacher and his students by moving informationtransmission teaching out of class and utilizing class time for practice and learning activities. Students have to prepare teachers' posted lessons at home and to do homework in class. This offers opportunities for teachers to devote all the class-time to discussion and interaction and to allow students to learn from practicing instead of listening passively to lecturing. The idea behind flipped learning is that students prepare educational content before class and engage in active learning during class sessions. In this perspective, Al-Zahrani (2015) asserts that the activities that customarily take place in the 
classroom are carried out outside the classroom through social learning platforms and vice versa.

The use of information technology seems to be of paramount importance in flipped classrooms. Vogelsang and Ollermann (2019) showed that cumulative digitalization and electronic teaching become a real challenge for universities and that flipped classroom is a special form of digital teaching and blended learning. Xin-Yue (2016) regarded this model as a sort of blended learning as the pre-class work is often characterized by online materials and the in-class time is dedicated to cooperative tasks. Moreover, van Alten, Phielix, Janssen, and Kester (2019) indicated that flipped learning may include either "the use of videos and/or computer technology before class" or any "activities before class such as reading material" (p. 2). The idea of the flipped classroom did not come from scratch. Teachers have always asked their students to prepare some materials at home and to come prepared for the classroom to understand better the lesson. Now, with the pervasive availability of information technology, the use of the flipped classroom has become more feasible. E-learning, the Learning Management Systems and other electronic means play a great role in assigning reading materials to students to review them at home before attending the classroom (Bawaneh, Moumene, \& Aldalalah, 2020). Nowadays, what lends support to the use of the flipped classroom is the availability of great quantities of online resources and YouTube videos. Teachers can also create new media materials using open electronic resources and online journal articles. Instead of dispensing a lecture and wasting time explaining the various concepts and related intricacies, the teacher involves students in discussing what they have already learned alone.

In this study, Kahoot is used as a means of instruction because of its pedagogical usefulness for dispensing lessons, quizzes and exercises. Teachers can either use ready-made teaching materials and practice activities available on the Kahoot site or elaborate their own and post them to their students. Digital games represent effective, motivating and experiential learning to students (Kili, 2005; Papastergiou, 2009). Similarly, Janet (2019) implemented a gamified flipped classroom and found that the group-based game task is more effective than the group discussion task for improving students' behavioral, cognitive, and motivational engagement and reducing their anxiety and reticence toward using English. Similarly, Wang (2015) found that the implementation of Kahoot into classroom lectures underpins student engagement. In the same vein, Likorish, Georgen, Owen, and Daniel (2017) conclude that the use of Kahoot enhances teaching and learning quality, minimizes distracting classroom behaviors and improves classroom dynamics, engagement, and motivation. Eventually, the study of Plump and LaRosa (2017) showed that using Kahoot in the classroom propels engagement and active learning. All these studies bear witness to the positive results of Kahoot in promoting students' understanding, motivation, engagement, autonomy and collaboration.

\section{Benefits of Flipped Classroom to Understanding Medical Physics Concepts}

Numerous studies found that flipped classroom has beneficial effects on students' education. In a seminal study, Bergmann and Sam (2012) showed the relevance of flipped classrooms through a sequence of video lectures for their classes to watch at home and assimilate. Far ahead, other instructors started using this new approach to teaching and gaining more time in class. The flipped classroom turns the traditional classroom on its head by changing teachers and students' roles in the educational operation. This blended form of learning utilizes technology for dispensing academic knowledge. As King (1993) states, the teacher's role should shift from that of a wise intellect who disseminates knowledge to that of a guide allocating class time to the construction of meaning rather than the transmission of knowledge. Henceforth, students become responsible for their learning. They are no longer regarded as passive recipients but as dynamic contributors in building up knowledge. They deploy efforts to comprehend the received information at home and to discuss it with their partners in the classroom under the guidance of the teacher.

Flipped learning has come into common parlance in research literature, but it is not yet worldwide applied. In recent years, Ozdamli and Asiksoy (2016) affirmed that flipped classroom learning is not well recognized in Turkey, but they introduced it to academics showing its benefits. Similarly, flipping classroom is not used in the Arab countries except for some experiments to explore its validity. Vogelsang and Ollermann (2019) stressed that the evaluation of this method of teaching has not yet been carried out. However, Seery (2015) surveyed 12 source articles to analyze the benefits and challenges of flipped learning in chemistry education at the university level and indicated that it becomes very popular among students and researchers for maximizing time, active learning, understanding, joy, satisfaction, and engagement. Seery (2015) also stressed the need to establish a framework for its implementation like constructivism as the prevalent learning theory in Physics for integrating new ideas with what students already know. In the same perspective, Liu and Wenzhong (2019) affirmed that the flipped classroom in China has become popular in higher education since 2012, but learners' perceptions and experience of this approach were under-researched particularly in business and management. In this context, Kehoe, Schofield, Branigan, and Wilmore (2018) showed that academic developers confront some challenges in applying flipped classrooms such as time constraints, interdisciplinary miscommunication, and change 
resistance, but they showed that a shift from "sage on the stage" to "guide on the side" raised teachers' confidence and students' satisfaction about ratings.

Numerous studies on flipped classroom learning revealed interconnected positive results. First off, Bergmann and Sams (2012, p. 20-33) advanced a sequence of reasons for using flipping learning: it helps all kinds of students with varying learning styles, enhances interaction and regulates classroom management. Arnold-Garza (2014) states that flipped learning enhances the effective use of class time, dynamic learning, interaction, autonomy and learning styles, but she showed that their fulfillment utterly depends on teacher right implementation. Again, Freeman et al. (2014) demonstrate that active learning plays a considerable role in enhancing student performance in science, engineering and mathematics. Jyothia and Penman (2017) also defend the flipped classroom because it caters for students' needs, diversity, flexibility, independence, reduced contact time, technological developments and electronic resources. Again, Gayeta (2017) found that flipped classroom improved student conceptual understanding of stoichiometry and recommended it as an alternative method to traditional teaching. Equally important, Tomas, Evans, Doyle, and Skamp (2019) reported that flipped learning heightened students' level of engagement and learning. Over again, Liu and Wenzhong (2019) showed that students held positive perceptions and preferred to have flipped classrooms in their future learning. Likewise, Broman and Johnels (2019) revealed that students preferred flipped learning for five desired learning characteristics: timely guidance and feedback, clarity and detail, flexibility of instruction, application of concepts and cognitive engagement. In sum, all these studies recommended the use of flipped learning because of its multifaceted benefits.

In addition to the above-mentioned single studies that showed the relevance of flipped classroom, some researchers carried out systematic reviews. For instance, O'Flaherty and Phillips (2015) conducted a comprehensive review of 28 articles on flipped classroom instruction in various disciplines and their educational outcomes. Although their results reveal improved academic performance and student/teacher satisfaction, they point to a dearth of conclusive evidence on scaffolding lifelong learning and 21st-century skills in education (p. 85). In the same direction, Lo, Hew, and Chen (2017) presented a synthesis of research in mathematics education and showed many benefits and challenges. Moreover, Karabulut-Ilgu, Cherrez, and Jahren (2018) directed a comprehensive review of 62 articles on the knowledge and practice in flipped learning in engineering and revealed acceptance amid engineering educators. They also recommended stakeholders to develop research-based action plans in how to promote and evaluate flipped classrooms. To explore the effects of the flipped classroom on learning outcomes, Al-Shabibi and Al-Ayasra (2019) used a 'bibliometric analysis' for 233 studies during 2012-2019. They found that this approach provided students with ample interaction, better learning achievement and adequate grounding for 21st-century education and work environments.

Along line with these reviews, Lundin, Rensfeldt, Hillman, Lantz-Andersson, and Peterson (2018) advanced a systematic review appraising 530 Scopus publications on flipped classrooms accessible until midJune 2016. They concluded that knowledge contributions about the flipping approach are rather scrappy and that their emphasis was on higher education and scientific streams with the US as the predominant area. Akçayır and Akçayır (2018) also presented a systematic review of the flipped classroom approach demonstrating various advantages. Correspondingly, Tütüncü and Aksu (2018) led a comprehensive review of 38 studies related to the use of the flipped learning in Turkey published from 2014 till 2017. They showed that most studies found that flipped classroom is more effective than traditional lecture-based classrooms in increasing students' achievement, attitudes, motivation and perspectives. Consistently, van Alten, Phielix, Janssen, and Kester (2019) carried out a meta-analysis of 114 studies that compared flipped and traditional classrooms in secondary and postsecondary education. They concluded that students in flipped classrooms attained considerably higher learning results than those in traditional classrooms and expressed equal satisfaction with the learning experience.

\section{Benefits of Flipped Classroom to Students' Motivation in Learning Physics}

Traditional classrooms are generally teachercentered where lecturing takes place while students usually listen, take notes and may ask questions if they do not understand. In addition, teachers may give students some activities to do in the classroom or assign them some activities as homework. This traditional approach considers students as empty buckets to fill in via knowledge transmission and enlightenment. Students become passive recipients believing that the truth comes out of teacher mouth. This propensity seems to kill student inquisitiveness and motivation for learning. Flipped classroom comes to the scene to propel student motivation. When students actively engage themselves in the learning process through their prereading and preparation for classroom presentation and discussion, they will enhance their comprehension and hence achieve better results. Indeed, literature is abundant on motivation due to the importance of this strong inner drive as a predictor of learning and ultimate realization of all needs and expectations (Atkinson,1964; Broussard \& Garrison, 2004; Deckers, 2018; deCharms, 1976; Stipek, 1996). 
Studies on the intrinsic relationship between motivation and achievement have been gaining traction worldwide. No one can deny the role that motivation plays in enticing learners to complete their studies successfully. Stipek and Weisz (1981) admitted "Studies demonstrating a relationship between personality or motivational variables and school achievement have proliferated in psychological research over the past two decades" (p. 101). Academics usually attempt to relieve students' effect and reluctance to study and try to enhance their academic engagement to a maximum. On this common issue of engagement that is customarily raised by teachers and parents, Linnenbrink and Pintrich (2003) set forth three principal types of academic engagement: behavioral, cognitive, and motivational. Behavioral engagement points out students' willingness to pay attention and participate in class. Cognitive engagement refers to the amount of time that students allocate to plan and monitor their learning. Motivational engagement denotes students' interest in their study and their affective attitudes towards their instructors and classmates.

A great deal of research was done on motivation. According to Reiss (2012), psychologists have established two types of motivation theories: dualistic theories that divide motivation into intrinsic vs. extrinsic and multifaceted theories that diagnose several genetically distinct motives. He also stressed that numerous scientists have then moved beyond the study of intrinsic-extrinsic motivation and corroborated multifaceted theories that contribute to a better understanding of this concept. More importantly, Deci and Ryan (2008) advanced an interesting theory of motivation including the concepts of 'extrinsic' versus 'intrinsic' motivation as well as self-determination. In a subsequent work, Deci and Ryan (1985) developed selfdetermination theory as a theoretical framework for motivation where learners manifest three areas of needs in their learning process: competence, autonomy, and relatedness. According to them, learners' intrinsic motivation can be achieved upon the accomplishment of these three needs. Departing from these studies, Abeysekara and Dawson (2015) argued for using selfdetermination theory and cognitive load theory as educational frameworks for flipped learning classrooms to cater for students' needs, autonomy and motivation and promote their relatedness and active collaborative learning. When students prepare their lessons in advance at their own pace, they reduce their cognitive load and enhance learning. In the same endeavor, Sergis, Sampson, and Pelliccione (2018) adopted the theoretical framework as developed by Deci and Ryan (1985) and found that flipped learning triggered student motivation, engagement, and self-determination.

Many other experimental studies have been carried out in recent years. Aşıksoy and Özdamlı (2016) compared the effects of the traditional method and the flipped classroom in a physics course. They found that the flipped model promoted achievement, motivation and self-sufficiency when adapted to Keller's ARCS (attention, relevance, confidence, and satisfaction) motivation model. In the same perspective, Xin-Yue (2016) surveyed the use of flipped learning for motivating English learners and assisting them in improving their communicative language skills. Significant progress has been noted in learners' investment of more time and effort before instruction and an enthusiastic participation and communication during class. Similarly, Su and Chen (2018) found that the paradigms of flipped learning and student question generation have positive impacts on students' learning motivation, attitudes, and engagement in higher education curriculum compared to traditional teaching methods.

In their effort to enhance students' motivation and effectiveness in learning, Chang, Song, and Fang (2018) set forth a motivation teaching model that incorporates 'attention, relevance, confidence, and satisfaction' (ARCS) and problem-based learning and applied it to a flipped classroom. The results showed that students in the experimental group overcome those in the control group in terms of the four dimensions of ARCS. Correspondingly enough, Chung and Lee (2018) investigated the impact of the flipped model on learning motivation and attitudes in a class of college physical therapy students. Their fallouts displayed significant differences in learning motivation (attention, relevance, confidence, satisfaction) and attitudes toward physical therapy. In a similar vein, Sergis, Sampson, and Pelliccione (2018) explored the impact of flipped learning on students' cognitive learning outcomes, level of satisfaction and needs for competence, autonomy and relatedness by adopting Self-Determination Theory and eventually reported positive findings.

The studies in this literary survey showed that flipped learning not only optimizes students' motivation but also yields positive interconnected results as well. In connection with this perspective, Bansal, Bansal, Ahmad, and Pandey (2020) compared the effects of flipped learning and traditional teaching on second-year medical students and concluded that the flipped classroom developed better positive attitudes and learning outcomes for both sexes. Casting light on the impact of the flipped model on students' gender, the study of Chiquito, Castedo, Santos, López, and Alarcón (2020 revealed that female students got significantly better grades when compared with males and that both of them gained more confidence in the knowledge they learned. More importantly, Moreno-Guerrero, RomeroRodríguez, López-Belmonte, and Alonso-García (2020) demonstrated that flipped learning enhanced the use of time in class, autonomy motivation, interaction, collaboration and content deepening compared to traditional training in water literacy at the first level of 
secondary education. In short, all these studies point out the various interwoven benefits of the flipped classroom approach. Yet, the very issue lies in teachers' mastery in preparing useful videos and tracking students' serious pursuits. In this context, Urfa (2018) showed that flipped learning popularity is due to its development of learners' academic achievement, satisfaction, motivation and active learning, but he maintained that the model requires educators' readiness and technical competency to prepare motivating videos and ensure that the learners watch them. The research literature showed that flipped classroom enhances students' motivation and many intertwined positive results.

\section{METHOD AND PROCEDURES}

The population of this study comprised all female students enrolled in the segregated College of Science at Imam Abdulrahman Bin Faisal University (IAU), Kingdom of Saudi Arabia in the academic year 2019-2020 where the college houses only female students and there is no science college for boys at all.

To implement this study in a naturalistic setting, existing intact classes were used (Obiedat, Kayed, \& Adass, 2016). Students come from different towns within the eastern region of Saudi Arabia. The population of this study is representative of almost all the existing social classes in this area in terms of age: 21 - 23 years. They are also homogenous in terms of their nationality, mother tongue (Arabic), exposure to English as a foreign language, educational system, and cultural background. Students are also from an approximately equivalent socio-economic status.

\section{Sample}

Four female classes of medical physics courses were participating in the experiment during the academic year 2019-2020 for two months at Imam Abdulrahman Bin Faisal University (IAU), Saudi Arabia. These classes were intentionally selected by using purposive sample technique because one of our colleagues, an instructor of medical physics, fervently volunteered to carry out the experiment and observe the outcomes of the flipping classroom method on his students. Therefore, he was the instructor for two experimental groups. Another colleague passionately shared with us this experiment, and he was in charge of dispensing the same contents of the course to the two control groups following the traditional method. At the outset, the researchers sought an ethics clearance from the university and signed a consent form. With support from the authors, the experimenter teacher explained to the students the flipped classroom procedures and subsequently received a positive response on their part expressing an intense craving to cooperate and explore this new method. The actual total samples consisted of 123 students including 58 students in the experimental
Table 1. Participants' Distribution by Teaching Methods

\begin{tabular}{lc}
\hline Group & $\mathrm{N}$ \\
\hline Flipped classroom & 58 \\
Conventional classroom & 65 \\
Total & 123 \\
\hline
\end{tabular}

groups and 65 students in the control groups. By the way, the researchers selected only female students because the cultural regulations in Saudi universities require that both males and females study separately. Table 1 shows the participants' distribution according to the teaching methods.

\section{Study Design}

The study uses the quasi-experimental factorial design due to the difficulty of assigning individual students randomly as required by experimental design (Gay \& Airasian, 2003). In this study, the sample classrooms were randomly divided into two groups: control and experimental. The study controlled the effects of pretest scores for both dependent variables PreConceptual Understanding (CU) and Pre-Students' Motivation Towards Learning Physics (SMTPL) to investigate the effects of flipped classrooms on $\mathrm{CU}$ and SMTPL among undergraduate students in the college of science at IAU University.

\section{Study Instrumentation}

This study used three research instruments for investigation:

1. The teacher's guide to the flipped classroom teaching method: The researchers and the instructor reformulated the content of the scheduled "Medical Physics" from the book approved by the college of science for the academic year 2019-2020 to make it compatible with the flipped classroom method and with the lesson implementation mechanisms. The instructor in the experimental group has used this manual after being validated by a panel of four experts comprising university lecturers: two of them holding a Ph.D. in science/physics education and two of them holding a Ph.D. in Medical Physics. The comments and recommendations approved by the arbitration board were taken into consideration.

2. The Understanding Test: The researchers elaborated on an understanding test according to a blueprint for the target content in Medical Physics approved by the science college at IAU, Saudi Arabia. The test consisted of multiple-choice questions asking about students' understanding of Medical Physics concepts. A panel of four experts of the same experts' manual referee team validated the understanding test. Some items were just readjusted while two items were deleted based on the experts' opinions. The final version of the understanding test included $22 \mathrm{MCQ}$ items (Appendix 1). To ensure the readability of the 
understanding test items, students' understanding and time needed for completion. We first administered a pilot test on one class $(\mathrm{N}=36)$ who were randomly selected from the same college but who did not take part in the main study. It was confirmed that all these students were not enrolled in the targeted medical physics course. However, the population in the college is homogeneous to the original population in terms of students' characteristics, ability and interest in learning. In light of the feedback received, some items were reworded, and the needed response time was identified by finding out the meantime span required for the pilot sample to complete the test. The mean periods (25 minutes) taken by the first female students and the last female students were computed. It is a common practice in achievement tests to delete one or more items depending on the difficulty and discrimination coefficient values. Results from the pilot sample test were scored, and then difficulty and discrimination coefficients were computed for individual items. Results showed that all the difficulty coefficients were between (0.35 - 0.78) and discrimination coefficients were more than 0.39. These statistical findings were acceptable for this purpose (Gay \& Airasian, 2003; Gay, Mills, \& Airasian, 2009; Obiedat, Kayed, \& Adass, 2016).

The calculation of the reliability coefficient of the test can be conducted via the test-retest technique. However, due to time constraints, we calculated the reliability coefficient through the Cronbach Alpha equation by using the SPSS program, which measures the internal consistency of the items. The reliability coefficient here reached (0.76). This result is considered (Good) acceptable for scientific research purposes used in this study (Gay \& Airasian, 2003; Gay, Mills, \& Airasian, 2009; Obiedat, Kayed, \& Adass, 2016).

3. The questionnaire on students' motivation towards learning physics: Based on the literature reviewed and the questionnaires on students' motivation towards learning, the instrument used in this study was adopted from Tuan, Chin, and Shieh (2005). This research instrument is commonly used by researchers to measure overall students' motivation because of its validity and reliability. It was divided into six scales: self-efficiency, active learning strategies, science learning value, performance goal, achievement goal, and learning environment stimulation. It is worthwhile to mention that all the above items were basically designed using the Likert-type 5-point scale [with 1=Strongly Disagree, 2= Disagree, 3= Neutral, 4= Agree, and 5=Strongly Agree].

To test the validity of this questionnaire, it was submitted to a board consisting of six experts holding a Ph.D. degree in physics, science teaching methods, and educational psychology. The experts were invited to give their opinions regarding the clarity and appropriateness of individual items and their suitability for gauging the goals designed to measure. In light of their feedback and comments, necessary adjustments were made to three items, and the instrument in its final version included 11 items. The researchers also calculated the reliability factor through the Cronbach Alpha equation and reached (0.73). This result is considered (Good) acceptable for scientific research purposes (Al-Kellani \& Al-Shraifeen, 2011; Gay, Mills, \& Airasian, 2009).

Regarding the internal validity used to make sure that the effect that happened because of the intervention (treatment: flipped classroom). The researchers controlled all external variables that may affect the results like: the content, the pre-test, videos, case studies, using technology, same professor for the experiment groups, using technologies, labs, handout and worksheets, .... etc.

\section{Implementation of the Study}

After ensuring the validity and reliability of the study instruments, identifying a study population and a study sample was the next step. The present researchers considered the following aspects:

\section{Instructor training}

The study sample was divided into two groups: the experimental group with the flipped classroom method and the control group with the conventional teaching method. Before the practical implementation of the study, the selected instructor was exposed to a two-day training workshop carried out for four hours per day with a total number of eight training hours. At the end of the first training day, the researchers asked the instructor to present any lesson from the booklets provided by the researchers with his assistant for the actual study during the second day of the training workshop. A group discussion was carried out to get feedback about the flipped classroom. The training was held in coordination with Science College. The purpose of this training was to enable the instructor to master the treatment teaching method of the flipped classroom. The instructor was informed that he would be a part of an experiment in which new instructional methods would be tested. He worked with the new method and learned how to use it with his students. In the present study, the focus was on "Medical Physics concepts". Regular classroom visits were scheduled by the researchers in coordination with the Science College and the instructor to track the actual implementation of the study in the classroom, especially the researchers were male; and based on the regulations, and males cannot enter the female building without permission in advance. In the Saudi universities' environment, male sections are totally separated from female sections. For the control group instructor, the researchers asked her to run the classes as usual without any change in the teaching method and without any guide or information. She only 
used the same understanding test before starting the Medical Physics units and delivered the students' pretest questionnaire at the commencement and post-test questionnaire at the end of the experiment for gauging students' motivation towards learning Physics.

\section{Teaching based on a flipped classroom}

It is worth mentioning that the flipped classroom was used for dispensing the program of Medical Physics for the experimental group for two months. Medical Physics is a branch of physics that uses physics techniques in the practice of medicine for the diagnosis and treatment of various human diseases. The introduction to this course includes concepts related to signal recognition, radiology, $\quad x$-ray, radiation oncology, electrocardiography, nuclear medicine, laser surgery, planar radiography, magnetic resonance, ultrasound, radiotherapy, and ionizing radiation. Pre- and postexams were supplied with questions to stimulate cognitive capacities via the use of Kahoot and develop learning skills and critical thinking.

Video or audio topics covering the main concepts available in the textbook accredited by the department were elaborated for students. Then, the researchers uploaded them through three different channels: University Learning Management System (Blackboard), Facebook, and WhatsApp. Simultaneously, an assignment comprising a worksheet as a task was uploaded. Students were instructed to go through the video or audio passages to prepare themselves before attending the classroom. Students were also directed to watch similar videos from the YouTube links sent through the same channels. The instructor sometimes sent some case studies, subject related articles, and experts' contacts (mobile numbers and emails). In the classroom, students were divided into groups containing 4-6 students and allowed group discussion on the concepts in their handouts. Then, the instructor conducted a classroom discussion, and students were sometimes directed to attend some experimental works in the laboratory. Eventually, students were requested to answer some questions using Kahoot as a tool for formative assessment in each class. Later, the instructor provided a short lecture (about 15-20 minutes) to elucidate the difficult concepts or theories that students found difficult to understand. As a facilitator and motivator, the instructor had the opportunity to let students work on tasks in collaboration with their peers to get an in-depth understanding of the subject.

\section{Teaching based on conventional method}

The conventional teaching method was also used for the control group to dispense the same contents delivered for the experimental group for two months. The instructor followed the traditional stages of presentation and practice. In the presentation stage, the
Table 2. Means and standard deviations of students' understanding of Medical Physics concepts

\begin{tabular}{lccc}
\hline Group & $\mathrm{N}$ & Mean & SD \\
\hline Flipped Classroom & 58 & 15.30 & 2.32 \\
Conventional Classroom & 65 & 11.77 & 2.49 \\
Total & 123 & 13.43 & 2.98 \\
\hline
\end{tabular}

lecturer presented the contents of the textbooks about medical physics in the form of lectures. She explained all the bits and pieces of the lesson and wrote the main ideas on the whiteboard. Students were required to follow and take notes. The instructor usually asked students some questions to check their comprehension. At the practice stage, students were presented with some exercises as problem-solving activities that they had to do in the classroom. All the exercises for this traditional approach were available in their textbooks. The amount of time allocated to traditional instruction was the same devoted to flipped classrooms. However, the role was reversed. The time dedicated to teacher presentation and explanation in the traditional classroom would be devoted to a discussion in the flipped classroom. Under the conventional teaching method, the instructor was the principal organizer and controller of the learning environment in the classroom. The teacher held full responsibility for the group and maintained appropriate classroom management. In this teacher-centered method, instructors regard students as passive recipients having 'knowledge holes' that need to be filled with information. Indeed, students usually sit at their desks and keep listening passively. In general, students endeavor to maximize their grades and fulfill competitive, individualistic goals (Bawaneh, 2019; Baz \& Bawaneh, 2008; Qablan, Jaradat, \& Al-Momani, 2010).

\section{RESULTS}

The purpose of this study was to investigate the effect of the flipped classroom on students' understanding of Medical Physics concepts and motivation towards learning Physics for female students in Science College at IAU. Data were collected through the analysis of information gathered from the instruments created for the study purpose. To answer the first question: "Is the use of the flipped classroom teaching method more effective than the conventional teaching method in heightening students' understanding of Medical Physics concepts?", the descriptive statistics (M, SD) were conducted, and the results are presented in Table 2.

Table 2 presents the overall means and standard deviations of each post-test score between the groups of teaching methods. The mean scores of the conventional group recorded students' understanding of Medical Physics concepts $(\mathrm{M}=11.77, \mathrm{SD}=2.49)$ and the flipped classroom $(\mathrm{M}=15.30, \mathrm{SD}=2.32)$ with a difference (3.53) in favor to the flipped classroom. Since the researchers have the results of the pretest and posttest of the study instruments for both understanding as well as 
Table 3. Results of ANCOVA for the students' understanding of Medical Physics concepts via teaching methods

\begin{tabular}{lcccccc}
\hline Source & Type III Sum of Squares & df & Mean Square & F & Sig. & Partial Eta Squared \\
\hline Corrected Model & $394.544 a$ & 2 & 197.272 & 34.327 & .000 & .364 \\
Intercept & 2365.189 & 1 & 2365.189 & 411.565 & .000 & .774 \\
Preunderstanding & 13.937 & 1 & 13.937 & 2.425 & .122 & .020 \\
Group & 384.319 & 1 & 384.319 & 66.875 & .000 & .358 \\
Error & 689.619 & 120 & 5.747 & & & \\
Total & 23272.000 & 123 & & & \\
Corrected Total & 1084.163 & 122 & & & \\
\hline
\end{tabular}

a. R Squared $=.364$ (Adjusted R Squared $=.353$ )

Table 4. Means for each item of students' motivation towards learning Physics ( $\mathrm{N}=123)$

\begin{tabular}{|c|c|c|c|c|c|}
\hline \multirow[t]{3}{*}{ No } & \multirow[t]{3}{*}{ Item } & \multicolumn{2}{|c|}{$\begin{array}{l}\text { Convention } \\
\text { al classroom } \\
(\mathrm{N}=65)\end{array}$} & \multicolumn{2}{|c|}{$\begin{array}{c}\text { Flipped } \\
\text { classroom } \\
(\mathrm{N}=58)\end{array}$} \\
\hline & & \multicolumn{4}{|c|}{ Motivation } \\
\hline & & Pre & Post & Pre & Post \\
\hline 1 & When learning new concepts in Physics, I connect them to my previous experiences. & 3.1 & 3.3 & 3.3 & 3.9 \\
\hline 2 & During the learning process, I attempt to make connections between the concepts that I learn. & 3.2 & 3.3 & 3.5 & 4.3 \\
\hline 3 & In Physics, I think it is important to participate in inquiry activities. & 3.1 & 3.0 & 2.7 & 3.4 \\
\hline 4 & I think that learning Physics is important because I stimulate my thinking. & 2.4 & 3.3 & 2.8 & 3.7 \\
\hline 5 & I feel most fulfilled when I feel confident about the content in a Physics course. & 2.7 & 2.4 & 2.9 & 3.7 \\
\hline 6 & During a Physics course, I feel most fulfilled when I can solve a difficult problem. & 2.7 & 3.1 & 2.3 & 3.4 \\
\hline 7 & During a Physics course, I feel most fulfilled when the instructor accepts my ideas. & 2.8 & 3.3 & 2.7 & 3.8 \\
\hline 8 & During a Physics course, I feel most fulfilled when other students accept my ideas. & 2.5 & 2.7 & 2.2 & 3.0 \\
\hline 9 & I am willing to participate in Physics course because the content is exciting and changeable. & 2.4 & 2.4 & 2.1 & 3.0 \\
\hline 10 & I am willing to participate in Physics course because the instructor uses a variety of teaching methods. & 2.8 & 2.9 & 2.6 & 3.3 \\
\hline 11 & I am willing to participate in the Physics course because students are involved in discussions. & 2.4 & 3.3 & 2.9 & 3.6 \\
\hline \multicolumn{2}{|c|}{ Overall } & 2.7 & 3.10 & 2.7 & 3.50 \\
\hline
\end{tabular}

motivation, either ANCOVA or MANCOVA can provide precise statistical measures for indicating individual differences between the participants in this study. However, we opted for ANCOVA because of its facile procedures in reading the results and presenting them clearly and straightforwardly. The results are presented in Table 3.

Comparing the scores of the teaching methods (flipped classroom and conventional classroom) on students' understanding of Medical Physics concepts showed that the impact of the innovative teaching method was statistically significant: $F=66.875$, $a<0.05$ where eta square statistic (0.358) indicated a large effect size (Cohen, 1988). It can be interpreted that the flipped classroom teaching method had a crucial effect on students' understanding of Medical Physics concepts.

To answer the second question of the study: "Is the use of the flipped classroom teaching method more effective than the conventional teaching method in enhancing students' motivation towards learning Physics?", researchers computed the Mean of the instrument prepared for this purpose, and the results are indicated in Table 4.

The results in Table 4 show that the Mean of the students' motivation towards learning Physics for both teaching methods: conventional classroom and flipped classroom in the pretest and posttest. The overall Mean for the post motivation of flipped classroom is 3.50 whereas it is 3.10 for the conventional classroom. This shows that the students' motivation towards learning
Table 5. Means and standard deviations of students motivation towards learning Physics

\begin{tabular}{lccc}
\hline Group & $\mathrm{N}$ & Mean & SD \\
\hline Flipped Classroom & 58 & 3.44 & 0.60 \\
Conventional Classroom & 65 & 3.10 & 0.47 \\
Total & 123 & 3.25 & 0.57 \\
\hline
\end{tabular}

Physics in the flipped classroom was more effective than the conventional one. The highest Mean of the tool questions of the post-test was 4.30 corresponding to the second item. This indicates that the students attempted to make connections between the concepts that they learned, and they were looking for meaningful learning. It was immediately followed by the first item with 3.90, mean indicating and supporting the highest mean that the students did their best to connect new concepts to their previous experiences and meaningful learning. However, item 9 came in the last order in terms of mean with 2.4 showing that the students did not participate in the interpretation of physics given in the traditional instructional packet and found that the subject was difficult. Under the flipped classroom model, the ways of delivering the content motivated the students to learn and understand better. Hence, they found the subject easy, exciting, and enjoyable. Then, the researchers calculated the Means and standard deviations associated with the two teaching methods, as shown in Table 5.

Table 5 presents the overall means and standard deviations of each post-test score between the groups of teaching methods. The mean scores of the conventional 
Table 6. The Results of ANCOVA for the students' motivation towards learning Physics

\begin{tabular}{lcccccc}
\hline Source & Type III Sum of Squares & df & Mean Square & F & Sig. & Partial Eta Squared \\
\hline Corrected Model & $7.257 \mathrm{a}$ & 2 & 3.628 & 13.614 & .000 & .185 \\
Intercept & 9.845 & 1 & 9.845 & 36.939 & .000 & .235 \\
Pre-Motivation & 3.125 & 1 & 3.125 & 11.726 & .001 & .089 \\
Group & 4.204 & 1 & 4.204 & 15.775 & .000 & .116 \\
Error & 31.982 & 120 & .267 & & & \\
Total & 1341.826 & 123 & & & & \\
Corrected Total & 39.239 & 122 & & & & \\
\hline
\end{tabular}

a. R Squared $=.185$ (Adjusted R Squared $=.171$ )

group recorded students' motivation towards learning Physics $(\mathrm{M}=3.08, \mathrm{SD}=0.47)$ and the flipped classroom $(\mathrm{M}=3.44, \mathrm{SD}=0.60)$, with a difference of $(0.36)$ in favor to the flipped classroom. To ascertain the validity of the differences, the researchers performed the ANCOVA analysis, and the results are presented in Table 6 .

Comparing the scores of the flipped classroom and conventional classroom teaching methods on students' motivation towards learning Physics, the results showed that the impact of the teaching methods were statistically significant: $F=15.775, a<0.05$. The eta square statistic (0.116) indicated a medium effect size (Cohen, 1988). It can be interpreted that the flipped classroom teaching method had a crucial effect on enhancing students' motivation towards learning Physics.

\section{DISCUSSION}

The numerous studies covered in the research literature provide clear evidence that the flipped classroom approach is more efficient than the traditional teacher-fronted lessons. Its efficiency for the advantage of university students seems to be multifaceted in essence. All the results of the surveyed research works affirm that this approach has not only beneficial effects on promoting understanding and motivation but also on triggering other important interconnected outcomes.

\section{Flipped Classroom Impact on Students' Understanding}

The study confirmed the first undertaken hypothesis that the flipped classroom enhances students' understanding of Medical Physics concepts. There is a great difference between students who come prepared to the classroom just to discuss the topic and those who come unprepared seeking new information from the teacher as the unique source of knowledge (Bawaneh, 2019; Bawaneh, Moumene, \& Aldalalah, 2020; Bawaneh, Zain, \& Salmiza, (2010b). Unlike traditional lectures, the flipped classroom allows students to devote out of class time to plan and build up their own lessons to be ready for classroom discussion. The results of this study corroborate the findings of numerous researches such as Al-Shabibi and Al-Ayasra (2019), Broman and Johnels (2019), Lage, Platt, and Treglia (2000), Sergis et al. (2018). Besides, the academic performance of students has also been observed due to action activity which is essential for fostering thinking (Obeidat \& Abu Al-Sameed, 2007; Plump \& LaRosa, 2017).

Flipped classroom seems to activate thinking by using effective skills, scientific augmentation, interpreting spectral data and eventually evaluating each spectrum (Al-Kellani \& Al-Shraifeen, 2011). The uniqueness of this approach is that it helps create more active learning opportunities and shifts the emphasis from the instructor's responsibility to students' responsibility for learning (Courts \& Tucker, 2012; Gannod et al., 2008). Peer-to-peer interaction is also enhanced with increased opportunities as they have healthy discussions with their classmates and converse in the language in which they feel stress-free and comfortable. These findings lend support to (Broman \& Johnels, 2019; Su \& Chen, 2018, Tütüncü \& Aksu, 2018). This learner-centered approach allows students to play an active role in learning and develop autonomy and positive attitudes towards understanding the subject matter. It enhances students' performance as it caters for students' needs, diversity, flexibility, independence, reduced contact time and electronic resources.

This study employs Kahoot in which the instructor's role is a facilitator creating an active environment in the classroom for participating in the discussion. The instructor creates audio-video clips, publishes through multimedia and allows students to go through before attending the class. Students will read, review and understand the topic at their own pace (Janet, 2019; Likorish et al., 2017). This endeavor had good returns on their time of hard work. In this perspective, the outcomes of this study corroborate this form of blended learning (Bawaneh, Moumene, \& Aldalalah, 2020; Broman \& Johnels, 2019; Janet, 2019; Jyothia \& Penman, 2017; Ollermann, 2019; Plump \& LaRosa, 2017; Villalba et al., 2018).

\section{Flipped Classroom Impact on Students' Motivation}

The study confirmed the second undertaken hypothesis that flipped classroom develops students' motivation towards learning physics. It systematically creates a relaxed atmosphere of thoughtfulness with the topic in the classroom. This corroborates previous findings (Chang et al., 2018; Sergis et al., 2018; Su \& Chen, 2018; Topcu \& Leana-Tascilar, 2018; Tütüncü \& $A k s u, 2018)$. Under this approach, there is a huge 
opportunity for learners to give judgmental opinions and interact in different instructional situations from which they become active and motivated learners. Indeed, no one can deny that motivation plays an effective role in the learning process. The present positive results are consistent with the findings of numerous studies referred to in the literature (Abeysekara \& Dawson, 2015; Akçayır \& Akçayır, 2018; Al-Zahrani, 2015; Bawaneh et al., 2012; Bergmann \& Sams, 2012; Chung \& Lee, 2018; Cole \& Kritzer, 2009; Deckers, 2018; Demirel, 2016; Freeman et al., 2014; Gayeta, 2017; Johnson et al., 2016; Jyothia \& Penman, 2017; Su \& Chen, 2018; Tütüncü \& Aksu, 2018).

\section{CONCLUSION}

This study investigates the effects of the flipped classroom on students' understanding of Medical physics concepts and their motivation towards learning physics. The findings corroborate the advanced hypotheses that the flipped learning classroom is more effective than the traditional classroom in enhancing students' understanding and motivation. As far as the first comprehension hypothesis is concerned, it seems quite evident that students who spend more time on preclass preparation of the required materials will be ready for understanding better than those students who come to the conventional classroom with no anticipation of the content at all. This positive result seems to be in symbiosis with the findings of recent research on the role of flipped learning in facilitating learning and consolidating comprehension and language skills (AlShabibi \& Al-Ayasra, 2019; Broman \& Johnels, 2019; O'Flaherty \& Phillips, 2015; Tomas et al., 2019).

Regarding the second hypothesis about motivation towards learning, this study revealed that the flipped classroom positively affected motivation. This was revealed through the collected students' attitudes that revealed great motivation and satisfaction. Likewise, the use of technology for obtaining instructional materials triggered students' engagement and heightened their autonomy for searching and gathering information. Additionally, the utilization of Kahoot represented a kind of gamification that provided plenty of opportunities for interaction and joyfulness.

However, the employment of the flipped classroom in this department is still in its infancy, so instructors need prompt training to be capable of applying it appropriately. Instructors are highly recommended to attend training workshops to learn how to use flipped classrooms during their lessons. They should be knowledgeable so that they can plan their instructional activities. This vehement requirement proves to be in symbiosis with teachers' technical competency that is strongly accentuated by many researchers (ArnoldGarza, 2014; Urfa, 2018; Vogelsang \& Ollermann, 2019). Students also need to familiarize themselves with this approach to become active and responsible for their learning.

When the flipped classroom is properly used, it likely results in students' better understanding, motivation and other interconnected outcomes. Based on the positive results evidenced in this study, we urged university instructors to consider flipped learning as a new alternative approach to be employed with their students. Besides, educators are called to implement it in designing scientific curricula. As such, this approach should, in no way, be estranged from pedagogical practice at university level.

\section{LIMITATIONS}

There are some limitations to this study that need careful consideration. First, this study experimented upon 123 Science female students at IAU, Saudi Arabia. Second, this study is also limited to the Medical Physics course in the Physics department. Besides, this research work is a case study; and for a deeper consideration, a longitudinal study should be conducted to appraise students' engagement and perseverance in such a demanding pre-class preparation of learning materials for the whole academic year. Future research may be carried out to check teachers' perceptions and employability of this model. Therefore, the generalization of the results may not be borne out for other students.

\section{REFERENCES}

Abeysekera, L., \& Dawson, P. (2015). Motivation and cognitive load in the flipped classroom: Definition, rationale and a call for research. Higher Education Research and Development, 34(1), 1-14. https:/ / doi.org/10.1080/07294360.2014.934336

Akçayır, G., \& Akçayır, M. (2018). The flipped classroom: A review of its advantages and challenges. Computers $\mathcal{E}$ Education, 126, 334-345. https:// doi.org/10.1016/j.compedu.2018.07.021

Al-Kellani, A., \& Al-Shraifeen, N. (2011). Introduction to research in education and social sciences ( $3^{\text {rd }}$ Ed.). Dar Al Masirah for Publishing, Distribution and Printing. Amman, Jordan.

Al-Shabibi, T. S., \& Al-Ayasra, M. A. (2019). Effectiveness of the flipped classroom strategy in learning outcomes (bibliometric study). International Journal of Learning, Teaching and Educational Research, 18(3), 96-127. https:/ / doi.org/10.26803/ijlter.18.3.6

Al-Zahrani, A. M. (2015). From passive to active: The impact of the flipped classroom through social learning platforms on higher education students' creative thinking. British Journal of Educational Technology, 46(6), 1133-1148. https:/ / doi.org/10.1111/bjet.12353 
Arnold-Garza, S. (2014). The Flipped Classroom Teaching Model and its use for information literacy instruction. Communications in Information Literacy 8(1), 1-16. https:// doi.org/10.15760/comminfolit. 2014.8.1.161

Aşıksoy, G., \& Özdamlı, F. (2016). Flipped Classroom adapted to the ARCS Model of Motivation and applied to a Physics Course. Eurasia Journal of Mathematics, Science \& Technology Education, 12(6), 1589-1603.

https:/ / doi.org/10.12973/eurasia.2016.1251a

Atkinson, J. W. (1964). An introduction to motivation. Princeton, N.J.: Van Nostrand.

Bansal, S., Bansal, M., Ahmad, K. A., \& Pandey, J. (2020). Effects of a flipped classroom approach on learning outcomes of higher and lower performing medical students: A new insight. Adv Educ Res Eval, 1(1), 2431. https:/ / doi.org/10.25082/ AERE.2020.01.005

Bawaneh, A. (2019). The effectiveness of using mind mapping on tenth-grade students' immediate achievement and retention of electric energy concepts. Journal of Turkish Science Education, 16(1), 123-138.

Bawaneh, A., Moumene, A., \& Aldalalah, O. (2020). Gauging the Level of Reflective Teaching Practices among Science Teachers. International Journal of Instruction, 13(1), 695-712. https://doi.org/ 10.29333/iji.2020.13145a

Bawaneh, A., Zain, A. N. M., \& Salmiza, S. (2010a). Radical conceptual change through teaching method based on constructivism theory for eight grade Jordanian students. The Journal of International Social Research, 3(14), 131-147. https:/ / doi.org/10.5539/ies.v3n1p96

Bawaneh, A., Zain, A. N. M., \& Salmiza, S. (2010b). Investigating students' preferable learning styles based on Herrmann's whole brain model for the purpose of developing new teaching method in modifying science misconceptions. Educational Research (ISSN: 2141-5161), International Research Journals, 1(9), 363-372.

Bawaneh, A., Zain, A. N. M., Salmiza, S., \& Abdul Ghani, K. (2012). The Effect of a Brain-Based Teaching Method on Conceptual Change in Students' Understanding of Electricity. International Journal of Physics \& Chemistry Education, 4(2), 79-96.

Bawaneh, A., Zain, A., \& Saleh, S. (2012). Using Herrmann Whole Brain Teaching Method to Enhance Students' Motivation towards Science Learning. Journal of Turkish Science Education, 9(3), 03-22.

Baz, T., \& Bawaneh, A. (2008). The effect of using conflict maps as an instructional tool in changing alternative conceptions of eight grade students in science in the Hashemite Kingdom of Jordan. The Educational Journal, 87(22) 149-189.

Bellanca, J. A., \& Brandt, R. S. (2010). 21st-century skills: Rethinking how students learn. Bloomington, IN: Solution Tree Press.

Bergmann, J., \& Sams, A. (2012). Flip your classroom: Reach every student in every class every day. International Society for Technology in Education

Broman, K., \& Johnels, D. (2019) Flipping the class: University Physics students' experiences from a new teaching and learning approach Physics Teacher International, 1(1), 20180004 https://doi.org/ 10.1515/cti-2018-0004

Broussard, S. C., \& Garrison, M. E. B. (2004). The relationship between classroom motivation and academic achievement in elementary school-aged children. Family and Consumer Sciences Research Journal, 33(2) 106-120. https://doi.org/10.1177/ $1077727 X 04269573$

Chang, Y. H., Song, A. C., \& Fang, R. J. (2018). Integrating ARCS model of motivation and PBL in flipped classroom: a case study on a programming language. EURASIA Journal of Mathematics, Science and Technology Education, 14(12), em1631. https:/ / doi.org/10.29333/ejmste/97187

Chiquito, M., Castedo, R., Santos, A. P., López, L. M., \& Alarcón, C. (2020). Flipped classroom in engineering: The influence of gender. Computer Applications in Engineering Education, 28, 80-89. https:// doi.org/10.1002/cae.22176

Chung, E. J., \& Lee, B. H. (2018). The effects of flipped learning on learning motivation and attitudes in a class of college physical therapy students, Journal of Problem-Based Learning, 5(1), 29-36. https:// doi.org/10.24313/jpbl.2018.5.1.29

Cohen, J. (1988). Statistical power analysis for the behavioral sciences. Hilisdale, NJ: Erlbaum. https:/ / doi.org/10.1002/bs.3830330104

Cole, J. E., \& Kritzer, J. B. (2009). Strategies for success: Teaching an online course. Rural Special Education Quarterly, 28(4), 36-40. https://doi.org/10.1177/ 875687050902800406

Courts, B., \& Tucker, J. (2012). Using technology to create a dynamic classroom experience. Journal of collage teaching and learning, 9(2), 121-128. https:/ / doi.org/10.19030/tlc.v9i2.6907

De Charms, R. (1976). Enhancing Motivation: Change in the Classroom. New York: Halsted.

Deci, E. L., \& Ryan, R. M. (2008). Self-determination theory: A macro theory of human motivation, development, and health. Canadian Psychology/Psychologie Canadienne, 49(3), 182. https:// doi.org/10.1037/a0012801 
Deci, E., \& Ryan, R. M. (1985). Intrinsic motivation and selfdetermination in human behavior. Springer Science \& Business Media. https://doi.org/10.1007/978-14899-2271-7

Deckers, L. (2018). Motivation: Biological, Psychological, and Environmental. New York: Routledge. https://doi.org/10.4324/9781315178615

Demirel, E. E. (2016). Basics and Key Principles of Flipped Learning: Classes Upside Down. International Journal of Languages, Literature, and Linguistics, 2(3), 109-112. https://doi.org/ 10.18178/IJLLL.2016.2.3.77

Flipped Learning Network, (2014). Definition of flipped learning. Retrieved from http://flippedlearning. org/domain/46

Freeman, S., Eddy, S. L., McDonough, M., Smith, M. K., Okoroafor, N., Jordt, H., \& Wenderoth, M. P. (2014). Active learning increases student performance in science, engineering, and mathematics. Proceedings of the National Academy of Sciences of the United States of America, 111(23), 8410-8415. https://doi.org/ $10.1073 /$ pnas.1319030111

Freeman, S., Eddy, S. L., McDonough, M., Smith, M. K., Okoroafor, N., Jordt, H., \& Wenderoth, M. P. (2014). Active learning increases student performance in science, engineering, and mathematics. Proceedings of the National Academy of Sciences, 111(23), 84108415. https:/ / doi.org/10.1073/pnas.1319030111

Gallagher, K. (2009). LOEX Conference Proceedings 2007: From guest lecturer to assignment consultant: Exploring a new role for the teaching librarian. Ypsilanti, MI: Eastern Michigan University. Retrieved from http://commons.emich.edu/cgi/ article $=1008 \&$ context $=$ loexconf2007

Gannod, G. C., Burge, J. E., \& Helmick, M. T. (2008). Proceedings of the $30^{\text {th }}$ International Conference on Software Engineering: Using the inverted classroom to teach software engineering. New York, NY: ACM. https://doi.org/10.1145/1368088.1368198

Gay, L. R., \& Airasian, P. W. (2003). Educational research: Competencies for analysis and application (7th Ed), Prentice-Hall. USA.

Gay, L. R., Mills, G. E., \& Airasian, P. (2009). Educational research: Competencies for analysis and applications $\left(9^{\text {th }}\right.$ Ed.). Upper Saddle River, NJ: Pearson, USA.

Gayeta, N. E. (2017). Flipped Classroom as an Alternative Strategy for Teaching Stoichiometry. Asia Pacific Journal of Multidisciplinary Research, 5(4), 83-89.

Janet, H. (2019). Gamifying the flipped classroom: how to motivate Chinese ESL learners? Innovation in Language Learning and Teaching. http:/ / Doi.10.1080/17501229.2019.1614185

Karabulut-Ilgu, A., Cherrez, N. J., \& Jahren, C. T. (2018). A systematic review of research on the flipped learning method in engineering education. British
Journal of Educational Technology, 49(3), 398-411. https:/ / doi.org/10.1111/bjet.12548

Kehoe, T., Schofield, P., Branigan, E., \& Wilmore, M. (2018). The Double Flip: Applying a Flipped Learning Approach to Teach the Teacher and Improve Student Satisfaction, Journal of University Teaching $\mathcal{E}$ Learning Practice, 15(1), 7. Retrieved from http:/ / ro.uow.edu.au/jutlp/vol15/iss1/7

Kili, K. (2005). Digital game-based learning: Towards an experiential gaming model. Internet and Higher Education, 8(1), 13-24. https://doi.org/10.1016/ j.iheduc.2004.12.001

King, A. (1993). "From sage on the stage to guide on the side." College teaching, 41(1), 30-35. https:/ / doi.org/10.1080/87567555.1993.9926781

Låg, T. R., \& Sæle, G. (2019). Does the flipped classroom improve student learning and satisfaction? A systematic review and meta-analysis. AERA Open, 5(3),

$1-17$. https:/ / doi.org/10.1177/2332858419870489

Lage, M. J., Platt, G. J., \& Treglia, M. (2000). Inverting the classroom: A gateway to creating an inclusive learning environment. Journal of Economic Education, 31(1), 30-43. https://doi.org/10.2307/ 1183338

Likorish, S. A., George, J. L., Owen, H. E., \& Daniel, B. K. (2017). "Go Kahoot!" Enriching Classroom Engagement, Motivation, and Learning Experience with Games. In W. Chen et al. (Eds.), Proceedings of the $25^{\text {th }}$ International Conference on Computers in Education (pp. 755-764). New Zealand: Asia-Pacific Society for Computers in Education.

Linnenbrink, E. A., \& Pintrich, P. R. (2003). The role of self-efficacy beliefs in student engagement and learning in the classroom. Reading $\mathcal{E}$ Writing Quarterly, 19(2), 119-137. https://doi.org/10.1080/ 10573560308223

Liu, D., \& Wenzhong Z.H.U. (2019). Students' Initial Experience of Flipped Classroom in Business and Management Education in China: Perceptions and Implications. Proceedings of the 2019 8th International Conference on Educational and Information Technology (pp. 124-130). https://doi.org/10.1145/3318396. 3318429

Lo, C. K., Hew, K. F., \& Chen, G. (2017). Toward a set of design principles for mathematics flipped classrooms: A synthesis of research in mathematics education. Educational Research Review, 22, 50-73. https:// doi.org/10.1016/j.edurev.2017.08.002

Lundin, M., Rensfeldt, A. B., Hillman, T., LantzAndersson, A., \& Peterson, L. (2018). Higher education dominance and siloed knowledge: a systematic review of flipped classroom research. International Journal of Educational Technology in 
Higher Education, 15(20),

https:/ / doi.org/10.1186/s41239-018-0101-6

Moreno-Guerrero, A. J., Romero-Rodríguez, J. M., López-Belmonte, J., \& Alonso-García, S. (2020). Flipped Learning Approach as Educational Innovation in Water Literacy. Water, 12(2), 574. https:// doi.org/10.3390/w12020574

Moumene, A. (2010). Grammar tasks and the learning of English as a Foreign Language. El-Tawassol (Annaba University Publications, Algeria), 25, 73-102.

Nowick, J. S. (2015). Organic Medical Physics. Retrieved from http://www.chem.uci.edu/jsnowick/organi cMedicalPhysics/index.html\#advancedstructurre

Obeidat, D., \& Abu Al-Sameed, S. (2007). Brain, teaching, and thinking. (1st ed.). Amman, Jordan: Dar Al-Fikr.

O'Flaherty, J., \& Phillips, C. (2015). The use of flipped classrooms in higher education: A scoping review. The Internet and Higher Education, 25, 85-95. https:// doi.org/10.1016/j.iheduc.2015.02.002

Overmyer, J. (2012, September). Flipped classrooms 101. Principal, 46-47.

Ozdamli, F., \& Asiksoy, G. (2016). Flipped classroom approach. World Journal on Educational Technology: Current Issues, 8(2), 98-105. https://doi.org/ 10.18844/wjet.v8i2.640

Papastergiou, M. (2009). Digital game-based learning in high school computer science education: Impact on educational effectiveness and student motivation. Computers \& Education, 52(1), 1-12. https:// doi.org/10.1016/j.compedu.2008.06.004

Plump, C. M., \& LaRosa, J. (2017). Using Kahoot in the classroom to create engagement and active learning: A game-based technology solution for eLearning novices. Management Teaching Review, 2(2), 151-158. https://doi.org/10.1177/237929811 6689783

Qablan, A., Jaradat, S., \& Al-Momani, I. (2010). Elementary Science Teachers' Perceptions of Educational Reform in Relation to Science Teaching in Jordan. Jordan Journal of Educational Sciences, 6(2), 161-173.

Reiss, S. (2012). Intrinsic and extrinsic motivation: Teaching of Psychology 39(2), 152-156. https://doi.org/10.1177/0098628312437704

Seery, MK. (2015). Flipped learning in higher education Physics: emerging trends and potential directions. Physics Education Research and Practice, 16, 758-768. https:// doi.org/10.1039/C5RP00136F

Sergis, S., Sampson, D. G., \& Pelliccione, L. (2018). Investigating the impact of Flipped Classroo9m on students' learning experiences: A SelfDetermination Theory approach. Computers in Human Behavior, 78, 368-378. https://doi.org/ 10.1016/j.chb.2017.08.011
Slaity, W. (2008). Learning based on the brain (1 $\left.{ }^{\text {st }} \mathrm{Ed}.\right)$. Amman, Jordan: Dar Al-Fikr.

Stipek, D. J. (1996). Motivation and instruction. In D. C. Berliner \& R. C. Calfee (Eds.), Handbook of Educational Psychology, 1, 85-113.

Stipek, D. J., \& Weisz J. R. (1981). Perceived Personal Control and Academic achievement. Review of Educational Research, 51(1), 101-137. https://doi.org/10.3102/00346543051001101

$\mathrm{Su}, \mathrm{C}$. Y., \& Chen, C. H. (2018). Investigating the effects of flipped learning, student question generation, and instant response technologies on students' learning motivation, attitudes, and engagement: A structural equation modeling. EURASIA Journal of Mathematics, Science and Technology Education, 14(6), 2453-2466.

https:/ / doi.org/10.29333/ejmste/89938

Thalluri, J., \& Penman, J. (2017). Sciences come alive for first-year university students through the flipped classroom. Third International Conference on Higher Education Advances. Universitat Politecnica de Valencia, Valencia. https:// doi.org/10.4995/HEAD17.2017.5169

Tomas, L., Evans, N., Doyle, T., \& Skamp, K. (2019). Are first-year students ready for a flipped classroom? A case for a flipped learning continuum. International Journal of Educational Technology in Higher Education, 16(5), 1-22. https://doi.org/10.1186/s41239-019$0135-4$

Topcu, S., \& Leana-Tascilar, M. Z. (2018). The role of motivation and self-esteem in the academic achievement of Turkish gifted students. Gifted Education International, 34(1), 3-18. https:// doi.org/10.1177/0261429416646192

Tuan, H., Chin, C., \& Shieh, S. (2005). The development of a questionnaire to measure students' motivation towards science learning. International Journal of Science Education, 27, 639-654. https://doi.org/ $10.1080 / 0950069042000323737$

Tütüncü, N., \& Aksu, M. (2018). A systematic review of flipped classroom studies in Turkish education. International Journal of Social Sciences and Education Research, 4(2), 207-229. https://doi.org/10.24289/ ijsser.405647

Urfa, M. (2018). Flipped Classroom Model and Practical Suggestions. Journal of Educational Technology $\mathcal{E}$ Online Learning, 1(1), 47-59. https://doi.org/ 10.31681/jetol.378607

Van Alten D. C. D., Phielix, C., Janssen, J., \& Kester, L. (2019). Effects of flipping the classroom on learning outcomes and satisfaction: A meta-analysis. Educational Research Review, 28, 1-18. https:// doi.org/10.1016/j.edurev.2019.05.003

Villalba, M. T., Castilla, G., \& Redondo-Duarte, S. (2018). Factors with influence on the adoption of the 
flipped classroom model in technical and vocational education. Journal of Information Technology Education: Research, 17, 441-469. https://doi.org/10.28945/4121

Vogelsang, K., \& Ollermann, F. (2019). Flipped classroom evaluation using the teaching analysis poll. 5th International Conference on Higher Education Advances (HEAd'19) Universitat Politecnica de Valencia, Valencia. https://doi.org/10.4995/ HEAd19.2019.9203
Wang, A. I. (2015). The wear-out effect of a game-based student response system. Computers $\mathcal{E}$ Education, 82, 217-227. https://doi.org/10.1016/j.compedu. 2014.11.004

Xin-Yue, Z. (2016). Motivation in a flipped classroom, a case study of teaching oral English in a vocational college in Mainland China. Sino-US English Teaching, 13(6), 460-467. https:/ / doi.org/10.17265/ 1539-8072/2016.06.004

\section{APPENDIX 1}

\section{The Distribution of Multiple-choice Items According to its Respective Subtopics}

(The correct answer highlighted)

\begin{tabular}{|c|c|c|}
\hline \multirow{6}{*}{$\begin{array}{l}\text { Items and } \\
\text { alternatives }\end{array}$} & \multicolumn{2}{|c|}{ 1. Which of the following is considered electromagnetic radiation (photons)? } \\
\hline & A. Electrons & B. Positrons \\
\hline & C. Protons & D. Gamma ray \\
\hline & \multicolumn{2}{|c|}{ 2. Which of the following interactions is considered the major contributor to the mass attenuation coefficient? } \\
\hline & A. Photon disintegration & B. Photoectric effect \\
\hline & C. Compton effect & D. Pair production \\
\hline \multicolumn{3}{|c|}{ Subject II: Interaction ionizing radiation with matter } \\
\hline \multirow{9}{*}{$\begin{array}{l}\text { Items and } \\
\text { alternatives }\end{array}$} & \multicolumn{2}{|l|}{ 3. Linear attenuation coefficient $(\mu)$ depends on: } \\
\hline & A. Energy of x-ray photons and atomic number & B. Electron density and wavelength \\
\hline & C. Atomic number and electron density & D. Energy of $x$-ray photons and electron density \\
\hline & \multicolumn{2}{|c|}{ 4. After traveling through two half-value layers, the incident radiation will reduce to: } \\
\hline & A. $100 \%$ & B. $50 \%$ \\
\hline & C. $25 \%$ & D. $12.5 \%$ \\
\hline & \multicolumn{2}{|l|}{ 5. Tenth value layer (TVL) is defined as: } \\
\hline & $\begin{array}{l}\text { A. Thickness of tissue which reduces the intensity of the X- } \\
\text { ray beam by a factor of one-fifth. }\end{array}$ & $\begin{array}{l}\text { B. Thickness of tissue which reduces the intensity of the X- } \\
\text { ray beam by a factor of one-fourth. }\end{array}$ \\
\hline & $\begin{array}{l}\text { C. Thickness of tissue which reduces the intensity of the X- } \\
\text { ray beam by a factor of one-tenth. }\end{array}$ & $\begin{array}{l}\text { D. Thickness of tissue which reduces the intensity of the X- } \\
\text { ray beam by a factor of one-half. }\end{array}$ \\
\hline \multicolumn{3}{|c|}{ Subject III: Instrumentation for planar radiography } \\
\hline \multirow{3}{*}{$\begin{array}{l}\text { Items and } \\
\text { alternatives }\end{array}$} & \multicolumn{2}{|c|}{ 6. Which of following factors is not contributed in Compton scatter X-ray? } \\
\hline & A. The geometry of the anti-scatter grid. & B. Increasing in Field of view (FOV) \\
\hline & C. The thickness of the body part & D. Low $\mathrm{kVp}$ \\
\hline \multicolumn{3}{|c|}{ Subject IV: Ionizing radiation } \\
\hline \multirow{9}{*}{$\begin{array}{l}\text { Items and } \\
\text { alternatives }\end{array}$} & \multicolumn{2}{|l|}{ 7. Which of the following is considered nonionizing radiation? } \\
\hline & A. Ultraviolet & B. X-ray \\
\hline & C. Infrared & D. Gamma ray \\
\hline & \multicolumn{2}{|c|}{ 8. Which of the following is considered particulate radiation (charged particle)? } \\
\hline & A. Ultraviolet & B. X-ray \\
\hline & C. Protons & D. Gamma ray \\
\hline & \multicolumn{2}{|c|}{ 9.Which of the following electromagnetic waves has high frequency and lower wavelength? } \\
\hline & A. Gamma ray & B. Ultraviolet \\
\hline & C. Radio wave & D. Infrared \\
\hline \multicolumn{3}{|c|}{ Subject V: X-ray tube and X-ray energy spectrum } \\
\hline \multirow{6}{*}{$\begin{array}{l}\text { Items and } \\
\text { alternatives }\end{array}$} & \multicolumn{2}{|l|}{ 10. Which of the following rays is emitted as spectrum? } \\
\hline & A. Characteristic X-ray & B. Gamma Ray \\
\hline & C. Bremsstrahlung X-ray & D. Electron \\
\hline & \multicolumn{2}{|c|}{ 11. In diagnostic X-ray imaging, which of the following interactions occur between $\mathrm{X}$-ray with tissue: } \\
\hline & A. Photoelectric interaction and Compton scattering & B. Photoelectric interaction and Pair Production \\
\hline & C. Compton Scattering and pair production & $\begin{array}{l}\text { D. Photoelectric interaction, Compton scattering and Pair } \\
\text { production }\end{array}$ \\
\hline
\end{tabular}




\begin{tabular}{|c|c|c|}
\hline \multicolumn{3}{|c|}{ Subject VI: Instrumentation for planar radiography } \\
\hline \multirow{3}{*}{$\begin{array}{l}\text { Items and } \\
\text { alternatives }\end{array}$} & \multicolumn{2}{|l|}{ 12. The collimator is placed between the: } \\
\hline & A. X-ray tube and the patient & B. Patient and the $\mathrm{X}$-ray detector \\
\hline & C. Collimator and the X-ray tube & D. Collimator and the Patient \\
\hline \multicolumn{3}{|c|}{ Subject VII: X-ray tube and X-ray energy spectrum } \\
\hline \multirow{3}{*}{$\begin{array}{l}\text { Items and } \\
\text { alternatives }\end{array}$} & \multicolumn{2}{|c|}{ 13. According to Heel effect, the X-ray beam has a lower intensity at the ___: } \\
\hline & A. Anode end & B. Cathode end \\
\hline & C. Detector end & D. Collimator end \\
\hline \multicolumn{3}{|c|}{ Subject VIII: Specialized X-ray imaging techniques } \\
\hline \multirow{3}{*}{$\begin{array}{l}\text { Items and } \\
\text { alternatives }\end{array}$} & \multicolumn{2}{|c|}{$\begin{array}{l}\text { 14. Which of the following techniques is used to investigate diseases such as stenosis and clotting of arteries and veins, } \\
\text { and irregularities in systemic blood flow? }\end{array}$} \\
\hline & A. Mammography & B. Fluoroscopy \\
\hline & C. Computed tomography & D. Subtraction angiography \\
\hline \multicolumn{3}{|c|}{ Subject IX: Instrumentation for planar radiography } \\
\hline \multirow{3}{*}{$\begin{array}{l}\text { Items and } \\
\text { alternatives }\end{array}$} & \multicolumn{2}{|c|}{ 15. Which of following instrument is used to reduce the contribution from secondary radiation to the image: } \\
\hline & A. Collimator. & B. Anti-scatter grid. \\
\hline & C. Digital detector. & D. X-ray tube \\
\hline \multicolumn{3}{|c|}{ Subject X: Interaction ionizing radiation with matter } \\
\hline \multirow{3}{*}{$\begin{array}{l}\text { Items and } \\
\text { alternatives }\end{array}$} & \multicolumn{2}{|c|}{ 16. If the half value layer is $2 \mathrm{~cm}$, the linear attenuation coefficient is: } \\
\hline & A. $0.50 \mathrm{~cm}^{-1}$ & B. $0.35 \mathrm{~cm}^{-1}$ \\
\hline & C. $2.9 \mathrm{~cm}^{-1}$ & D. $0.35 \mathrm{~cm}$ \\
\hline \multicolumn{3}{|c|}{ Subject XI: Introduction to MRI } \\
\hline \multirow{12}{*}{$\begin{array}{l}\text { Items and } \\
\text { alternatives }\end{array}$} & \multicolumn{2}{|c|}{ 17. Which of the following imaging techniques is considered non-invasive? } \\
\hline & A. MRI & B. Planar X-ray \\
\hline & C. CT & D. Nuclear Medicine \\
\hline & \multicolumn{2}{|l|}{ 18. MRI technique directly visualizes soft tissues in } \\
\hline & A.1 and 2-Dimension & B.2 and 3-Dimension \\
\hline & C.3-and 4-Dimension & D.4-Dimension \\
\hline & \multicolumn{2}{|l|}{ 19. The image intensity for MRI technique depends on: } \\
\hline & A. Number of protons and physical properties for tissues & B. Number of electrons and physical properties for tissues \\
\hline & C. physical properties for tissues & D. Number of neutrons and physical properties for tissues \\
\hline & \multicolumn{2}{|l|}{ 20. All the followings are considered disadvantages of MRI, except? } \\
\hline & $\begin{array}{l}\text { A. MR image acquisition is much slower than C. T and } \\
\text { ultrasound }\end{array}$ & B. A significant percentage of patients are precluded \\
\hline & $\begin{array}{l}\text { C. Systems are much more expensive than CT or ultrasound } \\
\text { units }\end{array}$ & $\begin{array}{l}\text { D. The produced image has the lowest soft-tissue contrast } \\
\text { comparing with other imaging techniques }\end{array}$ \\
\hline \multicolumn{3}{|c|}{ Subject XII: T1 and T2 relaxation times } \\
\hline \multirow{4}{*}{$\begin{array}{l}\text { Items and } \\
\text { alternatives }\end{array}$} & \multicolumn{2}{|c|}{ 21. The brain image of MRI technique has an excellent contrast between the gray and white matter of the brain } \\
\hline & A. True & B. False \\
\hline & \multicolumn{2}{|l|}{ 22. The bone is normally visible by using MRI technique. } \\
\hline & A. True & B. False \\
\hline
\end{tabular}

\section{http://www.ejmste.com}

